\title{
EFFECT OF TRINEXAPAC-ETHYL ON SUGARCANE VARIETIES
}

\author{
EFEITO DO TRINEXAPAC-ETHYL EM VARIEDADES DE CANA-DE-AÇÚCAR
}

\author{
Sebastião Ferreira de LIMA $^{1 *}$; Rita de Cassia Félix ALVAREZ ${ }^{1}$; \\ Vespasiano Borges de PAIVA NETO ${ }^{2}$; Cátia Aparecida SIMON ${ }^{3}$; \\ Maria Gabriela de Oliveira ANDRADE ${ }^{4}$
}

1. Doctor of Plant Science (Plant Production), Federal University of Mato Grosso do Sul, Chapadão do Sul Campus, Chapadão do Sul MS, Brazil. sebastiao.lima@ufms.br; 2. Doctor of Plant Physiology, Full Professor at the Federal University of Vale do São Francisco, Petrolina - PE, Brazil; 3. PhD student of Agricultural Microbiology Luiz de Queiroz School of Agriculture - University of São Paulo

(ESALQ); 4. MSc student of Plant Science at the "Júlio de Mesquita Filho" São Paulo State University - Ilha Solteira Faculty of Engineering, Ilha Solteira - SP, Brazil.

\begin{abstract}
Growth regulators have been widely employed as maturation inducers in the sugarcane crop, as an agricultural strategy. However, the response of varieties to the use of these compounds has been poorly studied, mainly in cerrado (savannah-like biome) areas occupied by the crop. This study was carried out to examine the effects of trinexapac-ethyl on important morphological characteristics of sugarcane varieties. The experiment was set up as a randomized block design with a $4 \times 2$ factorial arrangement consisting of four varieties (RB83-5054, SP80-1816, RB96-6928, and RB85-5156) associated or unassociated with application of trinexapac-ethyl (375 $\mathrm{g} \mathrm{L}^{-1}$ of the a.i. $\mathrm{ha}^{-1}$ ), with four replicates. The ripener was applied at 126, 178, and 228 days after planting (DAP) the first-cycle sugarcane, using the dose of $125 \mathrm{~g} \mathrm{~L}^{-1}$ a.i. ha ${ }^{-1}$ per application. Upon harvest, which occurred at 243 DAP, we determined the number of stalks per meter, weight of 30 stalks without top, internode length, number of internodes per stalk, and yield of sugarcane stalks. Ripener application increased the number of stalks in varieties RB96-6928 and RB83-5054 and the weight of 30 stalks in varieties RB96-6928 and RB83-5054 and SP80-1816; reduced internode length in varieties RB85-5156 and RB83-5054; and increased stalk yield per hectare in varieties RB96-6928 and RB83-5054, but did not increase the number of internodes per stalk in any of the tested varieties. The variables number of stalks, stalk weight, internode length, and stalk yield responded in a genotype-dependent manner to the application of trinexapac-ethyl.
\end{abstract}

KEYWORDS: Ripeners. Moddus ${ }^{\circledR}$. Plant growth regulator. Saccharum spp.

\section{INTRODUCTION}

As the producer of half of all sugar sold worldwide, Brazil should attain an average increase of $3.25 \%$ in sugar production by 2018/2019 and generate 47.34 million tons of the product. In terms of exports, the expected volume for 2019 is 32.6 million tons (BRASIL, 2015).

The efficiency of industrial sugar extraction depends on the quality of the raw material supplied to the industry. From the agro-industrial perspective, the maturation process should be conceptualized as the stage in which the crop exhibits the best qualitative and quantitative production of sugar (LEITE; CRUSCIOL, 2008; VIANA et al., 2008; SANTOS; BORÉM, 2013). This process has been anticipated through the use of growth regulators, or 'ripeners' (LAVANHOLI et al., 2002; ALMEIDA et al., 2003). At present, plant regulators are frequently applied in this crop, especially in major ethanol or sugar plants in view of need for anticipating the harvest and optimizing agricultural planning (SILVA; SEGATO, 2011; FARIA et al., 2014). Several chemical products such as trinexapac-ethyl, glyphosate, paraquat, fluazifop-pbutyl, and ethephon, in addition to sulfometuron methyl, are registered in Brazil for use as ripeners or plant growth regulators (ALMEIDA; LEITE; SOUZA, 2005).

According to Vianna et al. (2008), if applied properly and at the right time, trinexapac-ethyl is a plant growth regulator that promotes sucrose accumulation in the stalks and cell wall expansion, influencing the planning and maximization of the agro-industrial utilization of the sugarcane crop (RESENDE; SOARES; HUDTEZ, 2000). The use of trinexapac-ethyl in sugarcane has been the focus of many research studies that reported distinct responses regarding morpho-physiological parameters (LEITE et al., 2008; FARIA et al., 2014) and times of application (FARIA et al., 2015; VIANA; MUTTON; ZILLO, 2015).

Trinexapac-ethyl efficiently slowed the height-development process in sugarcane plants without influencing the stalk diameter, the number of stalks at harvest, or the weight of stalks per hectare (LEITE et al., 2008; FARIA et al., 2015). Trinexapac-ethyl is applied at the end of the crop 
cycle to increase the stalk sucrose content, advance maturation, and augment sugar production (FARIA et al., 2015).

The use of regulators during the crop cycle may be an interesting strategy especially in the production of sugarcane seedlings in nurseries, since their application throughout the cycle is aimed at reducing the plant height and the internode length and minimizing the lack of uniformity at harvest (CASTRO; KLUGE, 1999). The use of trinexapacethyl is expected to provide gains in the economic yield of the sugarcane crop. In this scenario, the present study was to examine the effect of trinexapac-ethyl on important morphological traits for the yield of sugarcane varieties.

\section{MATERIAL AND METHODS}

The experiment was implemented in a sugarcane area in the municipality of Chapadão do
Céu - GO, Brazil (52 32' 56" W, $18^{\circ}$ 24' 27" S, 725 $\mathrm{m}$ altitude). According to the Köppen classification, the climate in the region is an AW type, characterized as tropical-dry, with two well-defined seasons - dry and rainy — and an average annual precipitation of $1500 \mathrm{~mm}$. The months from April to September constitute the dry season, whereas the period from October to March represents the rainy season (Figure 1). The soil in the area is classified as a dystropic Red Latosol (Oxisol). Analyses performed at the depths of 0.0 to $0.25 \mathrm{~m}$ and 0.25 to $0.50 \mathrm{~m}$ revealed the following soil properties: $\mathrm{pH}$ in $\mathrm{CaCl}_{2}-5.3$ and 5.2; $\mathrm{OM}-30$ and $29 \mathrm{~g} \mathrm{dm}^{-3}$; $\mathrm{P}$ resin - 13 and $12 \mathrm{mg} \mathrm{dm}^{-3} ; \mathrm{S}\left(\mathrm{SO}_{4}\right)-30$ and $36 \mathrm{mg} \mathrm{dm}^{-3}$; $\mathrm{Ca}-27$ and $26 \mathrm{mmol}_{\mathrm{c}} \mathrm{dm}^{-3} ; \mathrm{Mg}-7$ and $6 \mathrm{mmol}_{\mathrm{c}}$ $\mathrm{dm}^{-3} ; \mathrm{K}-1.4$ and $0.9 \mathrm{mmol}_{\mathrm{c}} \mathrm{dm}^{-3} ; \mathrm{Al}-1.0$ and 1.0 $\mathrm{mmol}_{\mathrm{c}} \mathrm{dm}^{-3} ; \mathrm{H}+\mathrm{Al}-37$ and $41 \mathrm{mmol}_{\mathrm{c}} \mathrm{dm}^{-3} ; \mathrm{SB}-$ 35.4 and 32.9 mmol $_{\mathrm{c}} \mathrm{dm}^{-3}$; CEC - 72.4 and 73.9 $\mathrm{mmol}_{\mathrm{c}} \mathrm{dm}^{-3} ; \mathrm{V}-49$ and $45 \%$; and $\mathrm{m}-3.0$ and $3.0 \%$.

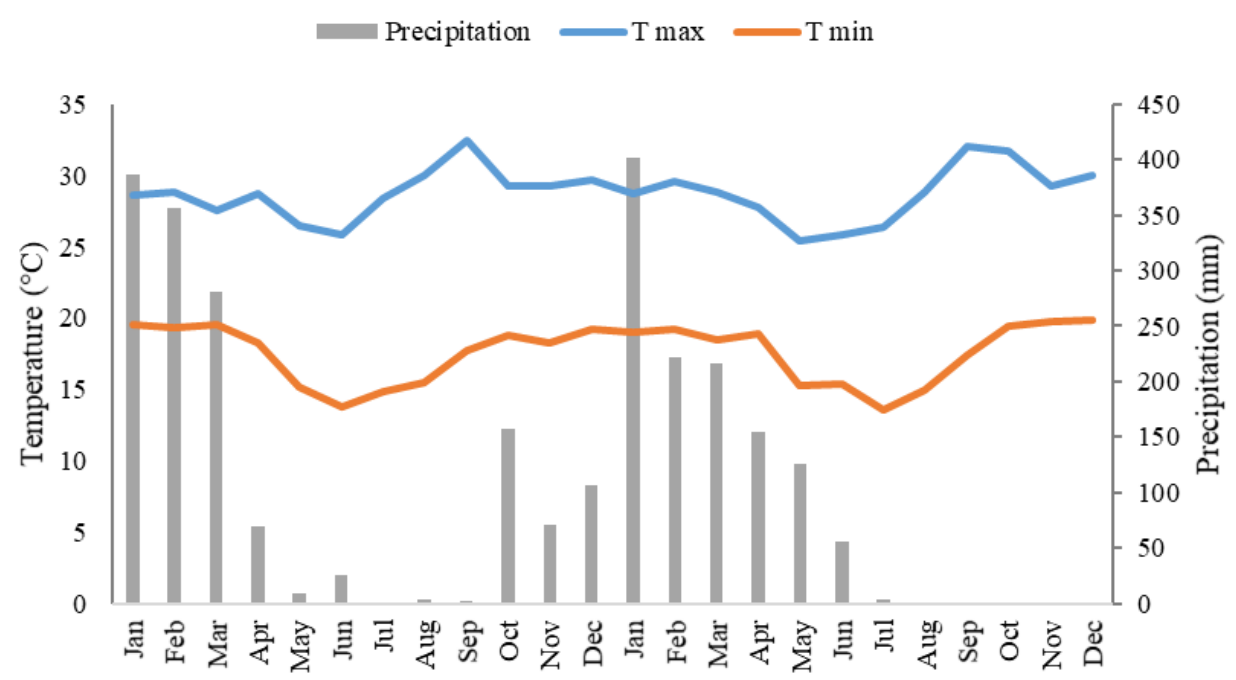

2011

2012

Figure 1. Precipitation and temperature observed during the 2011/2012 experimental period.

The experiment was set up as a randomizedblock design with a $4 \times 2$ factorial arrangement with four replicates. Treatments consisted of four varieties (RB83-5054, SP80-1816, RB96-6928, and RB85-5156, all in the first cycle), with or without application of trinexapac-ethyl $\left(375 \mathrm{~g} \mathrm{~L}^{-1}\right.$ of the a.i. $\mathrm{ha}^{-1}$ ). Plots were constituted by six 20-m sugarcane rows spaced $1.5 \mathrm{~m}$ apart. Only the two center rows were considered for the evaluation, discarding the 5 $\mathrm{m}$ of bordering.

The sugarcane (Saccharum spp.) genotypes tested in this study (RB83-5054, RB96-6928, RB85-
5156, and SP80-1816) are commercial varieties used industrially and employed in sugar and ethanol production. They originate from breeding programs developed at Federal Universities (Ridesa Interuniversity Network for the Development of the Sugar and Alcohol Sector) and at Coopersucar (Cooperative of Sugarcane, Sugar, and Alcohol Producers of São Paulo State). Variety RB83-5054 has an early/medium cycle, with medium tussock growth, upright and stalks poorly covered in straw; variety RB96-6928 has an early cycle with high shoot production and tillering rates; variety RB85- 
5156 has an early cycle, elevated tussock growth, and upright and straw-covered stalks; and variety SP80-1816 has a semi-early cycle, high shoot production and ratoon tillering rates, and upright stalks.

On June 5, 2011, the crop was planted using 180 seed pieces from 10-month-old seedlings per 20 $\mathrm{m}$ of furrow in each planting row, resulting in 18 to 20 viable buds per meter of furrow. Furrowing was performed at a depth of $0.40 \mathrm{~m}$, and fertilization was applied in the furrows with $700 \mathrm{~kg} \mathrm{ha}^{-1}$ of Yoorin (phosphate fertilizer that contains phosphorus (17.5\%), calcium (18\%), magnesium (7\%), and micronutrients ((B $(0.10 \%), \quad \mathrm{Cu} \quad(0.05 \%), \quad \mathrm{Mn}$ $(0.30 \%) \mathrm{Si}(10 \%)$, and $\mathrm{Zn}(0.55 \%))$ as FTE of high agronomic efficiency. The furrows were topdressed with $450 \mathrm{~kg} \mathrm{ha}^{-1}$ of the 08-28-20 formulation.

Trinexapac-ethyl was applied in three stages by an agricultural aircraft Ipanema model equipped with Micronair atomizers at a spray volume of $30 \mathrm{~L}$ $\mathrm{ha}^{-1}$. At the time of application, the relative humidity of the air was $67.0 \%$, the temperature was $24.6{ }^{\circ} \mathrm{C}$, and the wind speed was around $5.4 \mathrm{~km} \mathrm{~h}^{-1}$. The treatments were performed as follows: first application, with $125 \mathrm{~g} \mathrm{~L}^{-1}$ a.i. ha ${ }^{-1}$, at 126 days after planting (DAP); the second at 178 DAP with $125 \mathrm{~g} \mathrm{~L}^{-1}$ a.i. $\mathrm{ha}^{-1}$; and the third at 228 DAP with $125 \mathrm{~g} \mathrm{~L}^{-1}$ a.i. $\mathrm{ha}^{-1}$, totaling $375 \mathrm{~g} \mathrm{~L}^{-1}$ of the a.i. $\mathrm{ha}^{-1}$. To prevent control treatment from being contaminated, the area was protected with canvas during the application of the growth regulator. The area was canvased for 35 min to avoid any contact with the ripener and prevent the leaves from burning due to heating.

Upon harvest, which occurred at 243 DAP, all stalks within $10 \mathrm{~m}$ were harvested from the two rows of the usable area of each plot and counted. Of the total, 30 stalks without top were sampled and their total weight was determined using a scale. Subsemqently subsequently, stalk yield was determined in tons of sugarcane per hectare (TSH), based on the plot area. The number of internodes was counted in 10 sugarcane plants per plot and the internode length was measured in five plants per plot.

The data were subjected to analysis of variance, applying the $\mathrm{F}$ test at the $5 \%$ probability level. Tukey's test was performed $(\mathrm{P} \leq 0,05)$ to compare the effect of treatments (FERREIRA, 2011).

\section{RESULTS AND DISCUSSION}

Both evaluated factors (varieties [V] and application of trinexapac-ethyl [A]) significantly interfered with all biometric parameters evaluated. However, the $\mathrm{V} \times \mathrm{A}$ interaction effect did not significantly influence the biometric parameter number of internodes per stalk (Table 1).

Table 1. F values and coefficient of variation $(\mathrm{CV}, \%)$ for number of stalks in $10 \mathrm{~m}$ (Stalks $10 \mathrm{~m})$, weight of 30 stalks without top ( $\mathrm{Kg} 30$ stalks), internode length, number of internodes per stalk (N. of internodes), and stalk yield in tons of sugarcane per hectare (TSH) of different sugarcane varieties under the effect of trinexapac-ethyl. Chapadão do Céu/GO, 2012

\begin{tabular}{cccccc}
\hline \multirow{2}{*}{ Treatment } & \multicolumn{5}{c}{ F value } \\
\cline { 2 - 5 } & Stalks 10 m & Kg 30 stalks & Internode length & N. of internodes & TSH \\
\hline Varieties (V) & $42.84^{* *}$ & $113.16^{* *}$ & $142.13^{* *}$ & $9.38^{* *}$ & $90.71^{* *}$ \\
Application (A) & $6.45^{*}$ & $93.23^{* *}$ & $29.44^{* *}$ & $73.72^{* *}$ & $66.58^{* *}$ \\
V $\times$ A & $57.22^{* *}$ & $17.38^{* *}$ & $20.59^{* *}$ & $2.05^{\text {ns }}$ & $34.36^{* *}$ \\
\hline CV (\%) & 4.14 & 4.45 & 3.82 & 5.35 & 6.54 \\
\hline${ }^{* * *},{ }^{*}$ : significant at the 1\% and 5\% levels and insignificant, respectively.
\end{tabular}

In the decomposition of the variety $x$ trinexapac-ethyl application interaction, the varieties responded differently to ripener application for number of stalks in $10 \mathrm{~m}$ and weight of 30 stalks without top (Table 2). While varieties RB83-5054 and RB96-6928 had their stalk production increased by $32.5 \%$ and $8.5 \%$, respectively, with the application of the growth regulator, genotype SP801816 , had its production declined by $20.5 \%$ with the use of the ripener. These findings clearly demonstrate that the product stimulated tillering in varieties RB83-5054 and RB96-6928 and inhibited it in variety SP80-1816 (Table 2). Variety RB855156 did not have its tillering pattern altered by the 
application of the ripener. Faria et al. (2015) and Leite et al. (2008) worked with two varieties (RB867515 and SP80-3280, respectively) and found that trinexapac-ethyl changed several morphological factors and that this effect depended on the application time.

With the application of trinexapac-ethyl, variety RB83-5044 showed the highest number of stalks (157.00), which was $12.1 \%$ more than the 140.00 stalks obtained by variety SP80-1816 without the application of the growth regulator. However, with the application of the hormone, variety RB96-6928 produced only $2.2 \%$ less (137.00) than variety SP80-1816.

The heaviest weight of 30 stalks without top was obtained with the application of trinexapacethyl. Accordingly, the stalk weights obtained by varieties RB96-6928, RB83-5054, and SP80-1816 were $24.3 \%, 19.0 \%$, and $20.9 \%$ higher when the ripener was applied. Variety RB96-6928 had the best results for this parameter, generating $34.5 \mathrm{~kg}$ of fresh weight for 10 stalks without top.

As observed for number of stalks, variety RB85-5156 also did not respond to ripener application for stalk weight (Table 2). According to results published by Leite, Crusciol e Silva (2011), who worked with variety SP80-3280, trinexapacethyl efficiently slowed the height-development process in sugarcane plants without changing stalk diameter or the number of stalks at harvest. In the same way, the product did not alter stalk weight per hectare.

It should be emphasized that variety RB966928, which showed the largest tiller production with the use of the ripener, obtained the largest stalk weight in this condition, and these parameters are strong indicators of greater TSH.

Table 2. Decomposition of the variety $\times$ trinexapac-ethyl application interaction for number of stalks in $10 \mathrm{~cm}$ (Stalk $10 \mathrm{~m}$ ) and weight of 30 stalks without top (Kg 30 stalks) of sugarcane varieties under the effect of trinexapac-ethyl. Chapadão do Céu/GO, 2012

\begin{tabular}{cccccc}
\hline \multirow{2}{*}{ Variety } & \multicolumn{2}{c}{ Stalk $10 \mathrm{~m}$} & & \multicolumn{2}{c}{ Kg 30 stalks } \\
\cline { 2 - 3 } \cline { 5 - 6 } & Without & With & & Without & With \\
\hline RB83-5054 & $118.50 \mathrm{bcB}$ & $157.00 \mathrm{aA}$ & & $21.00 \mathrm{cB}$ & $25.75 \mathrm{cA}$ \\
SP80-1816 & $140.00 \mathrm{aA}$ & $111.25 \mathrm{cB}$ & & $25.13 \mathrm{bB}$ & $30.38 \mathrm{bA}$ \\
RB96-6928 & $126.25 \mathrm{bB}$ & $137.00 \mathrm{bA}$ & & $27.75 \mathrm{aB}$ & $34.50 \mathrm{aA}$ \\
RB85-5156 & $110.50 \mathrm{cA}$ & $108.75 \mathrm{cA}$ & & $22.00 \mathrm{cA}$ & $21.00 \mathrm{dA}$ \\
\hline
\end{tabular}

${ }^{1}$ Means followed by different lowercase letters in the column and uppercase letters in the row differ statistically by Tukey's test $(\mathrm{P} \leq 0.05)$.

The decomposition of the variety $x$ trinexapac-ethyl application interaction for internode length (Table 3) showed that the application of the ripener led to shorter internodes in varieties RB83-5054 and RB85-5156. The latter variety showed the lowest value for this variable, with and without the use of the regulator. The highest percentage reduction was seen in variety RB83-5054, whose internode length declined by $22.4 \%$ (Table 3). The other tested varieties (RB966928 and SP80-1816), in turn, did not respond to the ripener treatment, maintaining their internode length unchanged.

Variety RB85-5156, which showed the smallest internode length, had the highest number of internodes in absence of the growth regulator (Table 3). However, application of trinexapac-ethyl reduced the number of internodes per stalk regardless of the variety (Table 3 ). It is noteworthy that the main effect of gibberellins on plants is promoting cell elongation and division. Therefore, many substances that slow growth or cause dwarfism, among which is trinexapac-ethyl, act by inhibiting the biosynthesis of gibberellins, which, in the case of sugarcane, prompts maturation (RODRIGUES; LEITE, 2004; LEITE; CRUSCIOL; SILVA, 2011). The main mechanism of action of trinexapac-ethyl is reducing the endogenous levels of the most active form of gibberellic acid in plants $\left(\mathrm{GA}_{1}\right)$, compromising its biosynthesis from the precursor $\mathrm{GA}_{20}$ (RESENDE; SOARES; HUDTEZ, 2000; TAIZ et al., 2017).

In this study, the ripener led to shorter internodes but did not increase their quantity. The main interest in augmenting the latter variable is elevating the number of buds per stalk, which will consequently lead to increased production of sugarcane seedlings. A similar result with decreasing distances between buds was observed by Faria et al. (2015) at 200 days after emergence, with applications of trinexapac-ethyl. 
Table 3. Decomposition of the variety $\times$ trinexapac-ethyl application interaction for internode length $(\mathrm{cm})$ and number of internodes per stalk of sugarcane varieties under the effect of trinexapac-ethyl. Chapadão do Céu/GO, 2012

\begin{tabular}{cccc}
\hline \multirow{2}{*}{ Variety } & \multicolumn{2}{c}{ Internode length $^{1}$} & Number of internodes $^{1}$ \\
\cline { 2 - 3 } & Without & With & \\
\hline RB83-5054 & $13.58 \mathrm{bA}$ & $10.54 \mathrm{cB}$ & $10.04 \mathrm{~b}$ \\
SP80-1816 & $15.27 \mathrm{aA}$ & $15.92 \mathrm{aA}$ & $9.90 \mathrm{~b}$ \\
RB96-6928 & $13.57 \mathrm{bA}$ & $13.39 \mathrm{bA}$ & $10.03 \mathrm{~b}$ \\
RB85-5156 & $11.33 \mathrm{cA}$ & $10.11 \mathrm{cB}$ & $11.17 \mathrm{a}$ \\
\hline Application & & Number of internodes & \\
\hline With & & $9.45 \mathrm{~b}$ & \\
Without & & $11.12 \mathrm{a}$ & \\
\hline
\end{tabular}

${ }^{1}$ Means followed by different lowercase letters in the column and uppercase letters in the row differ statistically by Tukey's test $(\mathrm{P} \leq 0.05)$.

The decomposition of the variety $x$ trinexapac-ethyl application interaction for tons of stalks per hectare (TSH) indicated that the growth regulator provided a considerable increase in stalk production in varieties RB83-5054 and RB96-6928 (Table 4). The other varieties (SP80-1816 and RB85-5156) did not show alterations in stalk yield as affected by the application of the ripener. Thus, the use of trinexapac-ethyl increased the yield of variety RB96-6928 by $34.7 \%$, expanding its productive capacity, which was already outstanding even without application of the ripener. Despite not having great yields in absence of the growth regulator, variety RB83-5054 showed the greatest increase $(62.5 \%)$ in stalk yield with the use of the product, having its productive capacity considerably raised. Such alterations in productivity were also reported by Faria et al. (2015) and Leite et al. (2008). Faria et al. (2015) stated that trinexapacethyl application affects the consumed $\mathrm{CO}_{2}$, internal $\mathrm{CO}_{2}$ concentration, respiratory rate, stomatal conductance, and photosynthetic rate of sugarcane, and the magnitude of these alterations depends on the time and number of applications. When applied at 120 DAP or sequentially at 120,200 , and 240 DAP, trinexapac-ethyl provides positive increases in the variables that compose the photosynthesis process, which may result in better development and growth of the crop.

Table 4. Yield of sugarcane stalks in tons of sugarcane per hectare (TSH) at the harvest, under the effect of trinexapac-ethyl. Chapadão do Céu/GO, 2012

\begin{tabular}{ccc}
\hline \multirow{2}{*}{ Variety } & \multicolumn{2}{c}{ TSH $^{1}$} \\
\cline { 2 - 3 } & Without & With \\
\hline RB83-5054 & $55.29 \mathrm{bB}$ & $89.86 \mathrm{bA}$ \\
RP80-1816 & $78.19 \mathrm{aA}$ & $75.09 \mathrm{cA}$ \\
RB85-6928 & $77.95 \mathrm{aB}$ & $105.02 \mathrm{aA}$ \\
& $53.97 \mathrm{bA}$ & $50.73 \mathrm{dA}$ \\
\hline
\end{tabular}

${ }^{1}$ Means followed by different lowercase letters in the column and uppercase letters in the row differ statistically by Tukey's test $(\mathrm{P} \leq 0.05)$.

Considering the application of trinexapacethyl for all the analyzed variables, the responses were not uniform and are highly dependent on the variety. Variety RB96-6928 attained a prominent position in the experimental conditions as compared with the other genotypes. This outcome was a result of the beneficial effects of the ripener on aspects that are favorable for production, such as increases in the number and weight of stalks without a reduction of internode length. Therefore, an increase in number of stalks is only desirable when accompanied by an increase in stalk weight, since excessive stalks may cause self-shading and compromise $\mathrm{CO}_{2}$ fixation due to limiting photosynthetically active radiation (PAR) for the photochemical phase, resulting in a reduction of stalk weight. Thus, variety RB83-5054, which was initially promising, had a much lower stalk yield than that obtained by variety RB96-6928.

\section{CONCLUSIONS}

The total use of $375 \mathrm{~g} \mathrm{~L}^{-1}$ of the a.i. of trinexapac-ethyl per hectare split equally into doses of $125 \mathrm{~g} \mathrm{~L}^{-1}$ a.i. $\mathrm{ha}^{-1}$ at 126,178 , and 228 days after planting led to an increase in the number and weight 
of stalks in sugarcane varieties RB96-6928 and RB83-5054.
Trinexapac-ethyl was not favorable for the morphological and yield-related traits of sugarcane varieties SP80-1816 and RB85-5156.

RESUMO: O uso de reguladores de crescimento como indutores da maturação em cana-de-açúcar tem sido uma prática agrícola bastante empregada. Entretanto, a resposta das variedades à utilização desses compostos tem sido pouco estudada, principalmente em áreas de cerrado ocupadas pela cultura. O objetivo deste estudo foi avaliar os efeitos do trinexapac-ethyl em características morfológicas importantes para a produtividade de variedades de cana-de-açúcar. O delineamento experimental utilizado foi o de blocos casualizados em esquema fatorial 4 x 2, sendo quatro variedades (RB83-5054, SP80-1816, RB96-6928 e RB855156), combinadas com e sem aplicação de trinexapac-ethyl (375 $\mathrm{g} \mathrm{L}^{-1}$ do i.a. ha $\left.{ }^{-1}\right)$ e quatro repetições. A aplicação do maturador ocorreu aos 126, 178 e 228 dias após o plantio (DAP) da cana planta, com dose de 125 $\mathrm{g} \mathrm{L}^{-1}$ i.a. ha ${ }^{-1}$ por vez. Por ocasião da colheita, realizada aos $243 \mathrm{DAP}$, foram avaliados o número de colmos por metro, massa de 30 colmos sem ponteiro, comprimento de entrenós, número de entrenós por colmo e produtividade de colmos de cana-de-açúcar. Verificou-se que a aplicação do maturador incrementou o número de colmos para as variedades RB96-6928 e RB83-5054, a massa de 30 colmos para as variedades RB96-6928 e RB83-5054 e SP80-1816, maior redução no comprimento de entrenós para as variedades RB85-5156 e RB835054 e maior aumento na produção de colmos por hectare para as variedades RB96-6928 e RB83-5054, mas não aumentou o número de entrenós por colmo nas variedades testadas. A resposta das variáveis: número de colmos, massa de colmos, comprimento dos entrenós e produtividade de colmos à aplicação do trinexapac-ethyl mostrou-se genótipo dependente.

PALAVRAS-CHAVE: Maturadores. Moddus ${ }^{\circledR}$. Regulador de crescimento de plantas. Saccharum spp.

\section{REFERENCES}

ALMEIDA, J. C. V.; SANOMYA, R; LEITE, C. F. E; CASSINELLI, N. F. Eficiência Agronômica de Sulfometuron-Metil como Maturador na Cultura da Cana-de-Açúcar (Saccharum spp). STAB: Açúcar, Álcool e Subprodutos, Piracicaba, v. 21, n. 3, p. 36-37, 2003. https://doi.org/10.5433/1679-0359.2005v26n4p441

ALMEIDA, J. C. V.; LEITE, C. R. F.; SOUZA, J. R. P. Efeitos de maturadores nas características tecnológicas da cana-de-açúcar com e sem estresse hídrico. Semina: Ciências Agrárias, Londrina, v. 26, n. 4, p. 441-448, out./dez. 2005.

CASTRO, P. R. C.; KLUGE, R. A. Ecofisiologia de cultivos anuais: trigo, milho, soja, arroz e mandioca. 1. ed. São Paulo: Nobel, 1999. 126 p.

FARIA, A. T.; FERREIRA, E. A.; ROCHA, P. R. R.; SILVA, D. V.; SILVA, A. A.; FIALHO, C. M. T.; SILVA, A. F. Effect of trinexapac-ethyl on growth and yield of sugarcane. Planta Daninha, Viçosa, v. 33, n. 3, p. 491-497, 2015. http://dx.doi.org/10.1590/S0100-83582015000300011.

FARIA, A. T.; SILVA, A. F. da; FERREIRA, E. A.; ROCHA, P. R. R.; SILVA, D. V.; SILVA, A. A. da; TIRONI, S. P. Alterações nas características fisiológicas da cana-de-açúcar causadas por trinexapac-ethyl. Revista Brasileira de Ciências Agrárias (Agrária), Recife, v. 9, n. 2, p. 200-204, jan. 2014. https://doi.org/10.5039/agraria.v9i2a3783

FERREIRA, D. F. Sisvar: a computer statistical analysis system. Ciência e Agrotecnologia, Lavras, v. 35, n. 6, p. 1039-1042, nov./dec. 2011. https://doi.org/10.1590/S1413-70542011000600001 
LAVANHOLI, M. das G.D.P.; CASAGRANDE, A.A.; OLIVEIRA, L.A.F.; FERNANDES, G. A.; ROSA, R.F. Aplicação de ethephon e imazapyr em cana-de-açúcar em diferentes épocas e sua influência no florescimento, acidez do caldo e teores de açúcares nos colmos - variedade SP70-1143. STAB: Açúcar, Álcool e Subprodutos, Piracicaba, v. 20, p. 42- 45, 2002.

LEITE, G. H. P.; CRUSCIOL, C. A. C. Reguladores vegetais no desenvolvimento e produtividade da cana-deaçúcar. Pesquisa Agropecuária Brasileira, Brasília, v. 43, n. 8, p. 995-1001, ago. 2008. http://dx.doi.org/10.1590/S0100-204X2008000800007.

LEITE, G. H. P.; CRUSCIOL, C. A. C.; SILVA, M. S.; VENTURINI FILHO, W. G. Reguladores vegetais e qualidade tecnológica da cana-de-açúcar em meio de safra. Ciência e Agrotecnologia, Lavras, v. 32, n. 6, p. 1843-1850, nov./dez. 2008. http://dx.doi.org/10.1590/S1413-70542008000600024.

LEITE, G. H.; CRUSCIOL, C. A. C.; SILVA, M. A. Desenvolvimento e produtividade da cana-de-açúcar após a aplicação de reguladores vegetais em meio de safra. Semina: Ciências Agrárias, Londrina, v. 32, n. 1, p. 129-138, jan./mar. 2011. https://doi.org/10.5433/1679-0359.2011v32n1p129

MAPA. Ministério da Agricultura, Pecuária e Abastecimento. Cana-de-açúcar. Disponível em: $<$ http://www.agricultura.gov.br/vegetal/culturas/cana-de-acucar>. Acesso em: 26 de nov. 2015.

RESENDE, P. A. P.; SOARES, J. E.; HUDTEZ, M. Moddus ${ }^{\circledR}$, a plant growth regulator and management tool for sugarcane production in Brazil. Sugar Cane International, Glamorgan, v. 103, n. 1225, p. 5-9, 2000.

RODRIGUES, T. J. D.; LEITE, I. C. Fisiologia vegetal: hormônios das plantas. 1 ed. Jaboticabal: FUNEP, 2004. $78 \mathrm{p}$.

SANTOS, F.; BORÉM, A. Cana-de-açúcar: do plantio à colheita. $1^{\text {a }}$ ed. Viçosa, MG: UFV, 257 p. 2013.

SILVA, R. F. D. S.; SEGATO, S. V. Importância do uso de maturadores vegetais na cultura da cana-de-açúcar. Nucleus, Ituverava, v. 8, n. 2, p. 35-46, out. 2011. https://doi.org/10.3738/1982.2278.510

TAIZ, L.; ZEIGER, E.; MOLLER, I. M.; MURPHY, A. Fisiologia e desenvolvimento vegetal. 6 ed. Porto Alegre: ARTMED, 2017. 858 p.

VIANA, R. S.; MUTTON , M. A.; ZILLO, H. Índices de maturação da cana-de-açúcar quando submetida à aplicação de maturadores químicos. Revista Mirante, Anápolis, v. 8, n. 1, p. 99-109, jun. 2015.

VIANA, R. S.; SILVA, P. H.; MUTTON, M. A.; MUTTON, M. J. R.; GUIMARÃES, E. R.; BENTO, M. Efeito da aplicação de maturadores químicos na cultura da cana-de-açúcar (Saccharum spp) variedade SP813250. Acta Scientiarum Agronomy, Maringá, v. 30, n. 1, p. 65-71, Jan./Mar. 2008.

https://doi.org/10.4025/actasciagron.v30i1.1130 